\title{
Genetic Variation in the Bank Vole Clethrionomys glareolus: Biochemical Differentiation Among Populations over Short Geographic Distances
}

\author{
Maria LEITNER \& Günther B. HARTL *
}

\begin{abstract}
Leitner M. \& Hartl G. B., 1988: Genetic variation in the bank vole Clethrionomys glareolus: Biochemical differentiation among populations over short geographic distances. Acta theriol., 33, 16:231-245 [With 3 Tables \& 2 Figs.]
\end{abstract}

Electrophoretic variation in enzymes encoded by 51 presumptive structural loci was examined in 13 populations of the bank vole Clethrionomys glareolus (Schreber, 1780) from eastern Austria. The mean fraction of polymorphic loci $(\overline{\mathrm{P}})$ was 0.158 (range $0.078-0.216$ ), mean heterozygosity $(\vec{H})$ per individual was estimated to be 0.057 (range $0.028-0.085$ ). These data are similar to the mean values for rodents. Within the study area 7 old stocks (group I) can be distinguished from 6 newly established populations (group II), which root back to immigrations in areas of afforestation within the last three decades. In the latter, genetic variation was lower than in group I, but genetic diversity between populations was considerably higher. $\overline{\mathrm{P}}$, $\overline{\mathrm{H}}$, and heterozygosity in $M O D, I D H-2, P G M-2$ and $E S-D$ were significantly correlated with environmental variables, but most of these correlations are apparent only in group I. Our results suggest, that the amount and distribution of enzyme variation among group II populations is determined mainly by random factors, whereas among group I populations part of the enzyme polymorphism may also be based on adaptive processes.

[Säugetiersammlung des Naturhistorischen Museums Wien, Burgring 7, A-1010 Vienna, Austria and Forschungsinstitut für Wildtierkunde der Veterin "rmedizinischen Universität Wien, Savoyenstrasse 1, A-1160 Vienna, Austria]

\section{INTRODUCTION}

Concerning the evolutionary significance of enzyme polymorphism it is an important question, what proportion of differences in allozyme variation among populations or species is based on adaptive rather than on stochastic processes. Several environmental correlates of enzyme variation across species were described and reviewed by Nevo (1983a, b). He drew the conclusion that ecological variables explain at least a third of the genetic variance. However, more detailed analyses are necessary "to evaluate directly the hypothesized causal environmental relation through biochemical kinetic and physiological function, and assess their

\footnotetext{
* to whom correspondence should be addressed.
} 
presumed differential contribution to fitness" (Nevo, 1983a; see also Clarke, 1975, and Lewontin, 1985). To study those relationships in mammals, we chose a species which on one hand is inhabiting a variety of different biotopes and, on the other hand, can be subjected to direct experimental studies (breeding experiments). The bank vole, Clethrionomys glareolus, representing the most abundant group of recent rodents, the voles, is distributed almost all over Europe except of its southernmost and northernmost parts (Raczyński, 1983). It can inhabit a wide range of biotopes, even different ecosystems, with a zonal geographic variability in habitat preference (Pucek, 1983). In Austria, besides other

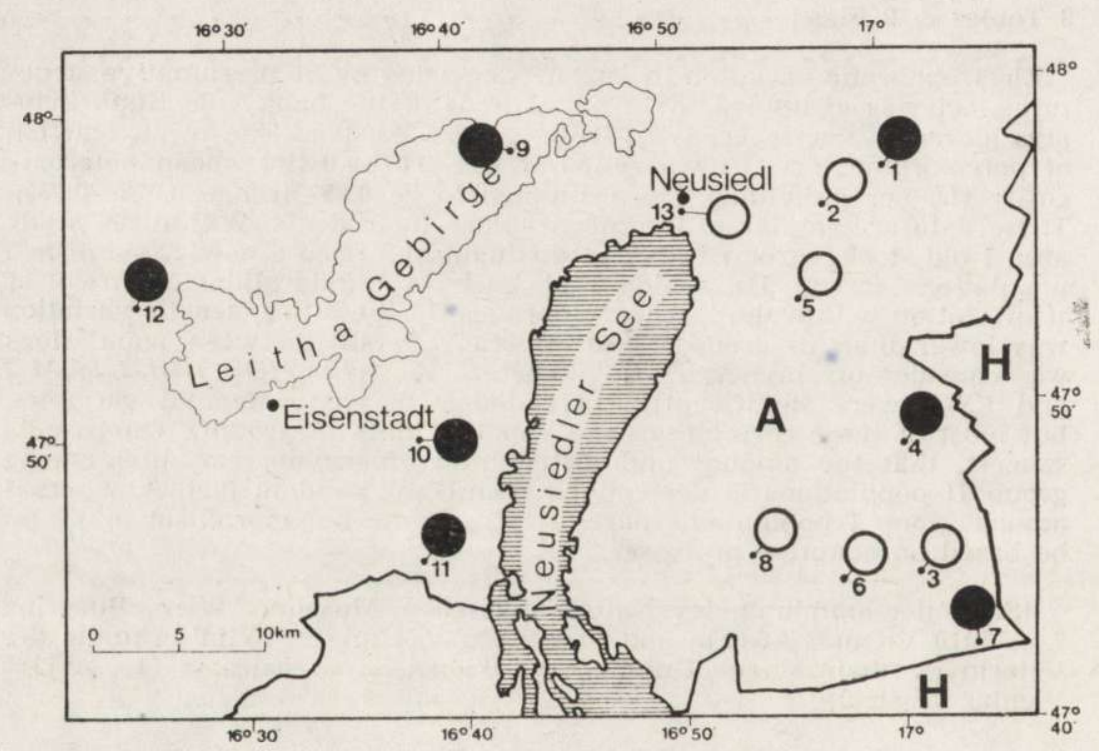

Fig. 1. Distribution of bank vole populations in the Neusiedlersee-region. Points populations of group I, circles - populations of group II, A - Austria, H Hungary,

locations, bank vole populations can be found in different biotopes within a small geographic area around the Neusiedlersee. This region is situated between the edge of the Alps in the west and the Pannonic Plain in the east and it may be unique in Europe with respect to drastic spatial changes in environmental conditions. Contrasting types of ecological units such as sandy and saline regions (Frasl, 1961; Husz, 1962), grassy puszta and swamps (Wendelberger, 1954; Weiser, 1970; Schuster, 1977), a forest belt (Hübl, 1959) and relicts of steppes (Schuster, 1977; Köllner, 1983) can be found side by side. Through human activity part of the natural landscape patterns and vegetation of the Neusiedlersee region 
has changed in the course of the last thirty years. New habitats for the bank vole have arisen by afforestation of small forest patches. Therefore old stocks of C. glareolus occur beside young insular populations (Fig. 1).

Population genetic studies in the bank vole using electrophoretic techniques have already been conducted in Poland with respect to genetic changes in seasonal generations (Fedyk \& Gębczyński, 1980) or different fitness of esterase allozyme phenotypes under laboratory conditions (Wójcik \& Fedyk, 1984). In the present study we evaluate genetic variation in the bank vole at a relatively large number of enzyme loci, considering a different extent of polymorphism among various classes of biochemical characters as explained in various ways e.g. by Johnson (1974, 1976), Ward (1977), Gillespie \& Langley (1974), Ayala \& Powell (1972), Sarich (1977) and Lewontin (1985). Indices of genetic variation found in our study showed values comparable to the mean values in rodents. Furthermore our results suggest, that biochemical differentiation within and among newly established populations is largely determined by founder effects and random drift, whereas in old populations part of the isozyme variability is associated with environmental variables.

\section{MATERIAL AND METHODS}

\subsection{Collection of Samples and Ecological Data}

Thirteen populations of the bank vole were investigated in the Neusiedlerseeregion in the SE part of Austria between longitude $16^{\circ} 24^{\prime}$ and $17^{\circ} 3^{\prime}$ and latitude $47^{\circ} 42^{\prime}$ and $47^{\circ} 57^{\prime}$ ) (Fig. 1). A total of 108 individuals was collected by snap-trapping in August 1986. Liver, kidney, spleen, heart, brain and muscle were prepared and stored at $-20^{\circ} \mathrm{C}$ for electrophoretic studies. Sampling localities represented different types of forest biotopes. To characterize the ecological background of the bank vole in our region several cological, physical, biotic and soil factors were recorded at the sampling sites:

- Ecological data: Size of habitat (in ha, based on interpretation of aerial photographs), population density (number of animals per 100 trap-nights; all data on population densities are the results of a two-year study of small mammal communities in the Neusiedlersee-region; Leitner, 1987).

- Physical data: Mean temperature $\left({ }^{\circ} \mathrm{C}\right.$; annual/January/July), mean annual rainfall, mean maximal snow cover $(\mathrm{cm})$. All climatological data are unpublished multiple year averages, based on 20 years of recordings. All records are derived from the closest meteorological station to the site of each bank vole population studied. Light intensity on the floor (average of daily recordings at 10 spots in the habitat over a period of one month - July).

- Biotic data: Tree density (number of trees per $100 \mathrm{~m}^{2}$; point-quarter method after Greig-Smith, 1964), shrub cover (in per cent; line-intercept method after Smith, 1980).

- Soil factors: Moisture capacity of soil (Mühlenberg, 1976), soil acidity (with electronic pH-meter) and soil salinity (in $\mu$ s with salinity-meter). 


\subsection{Electrophoretic Methods}

Preparation of tissue homogenates and horizontal starch gel electrophoresis were performed according to standard methods (Hartl \& Höger, 1986). Enzymes were visualized using the staining procedures described by Harris \& Hopkinson (1976), Shaw \& Prasad (1970) and Siciliano \& Shaw (1976).

The following 33 enzyme systems were screened (abbreviation, E.C. number and tissue used are given in parentheses: $\mathrm{L}=$ liver, $\mathrm{K}=$ kidney, $\mathrm{H}=$ heart, $\mathrm{M}=$ sceletal muscle, $B=$ brain): alcohol dehydrogenase (ADH/E.C. 1.1.1.1/L), $\alpha$-glyceropyhosphate dehydrogenase (GDC/E.C. 1.1.1.8/L), sorbitol dehydrogenase (SDH/E.C. 1.1.1.14/L), lactate dehydrogenase (LDH/E.C. 1.1.1.27/K), malate dehydrogenase (MOR/E.C. 1.1.1.37/K), malic enzyme (MOD/E.C. 1.1.1.40/K), isocitrate dehydrogenase (IDH/E.C. 1.1.1.42/K), 6-phosphogluconate dehydrogenase (PGD/E.C. 1.1.1.44/K), glucose dehydrogenase (GDH/E.C. 1.1.1.47/L), glucose-6-phosphate dehydrogenase (GPD/E.C. 1.1.1.49/L), glyceraldehyde-phosphate dehydrogenase (GAPDH/E.C. 1.2.1.12/M), xanthine dehydrogenase (XDH/E.C. 1.2.3.2/L), glutamate dehydrogenase (GLUD/E.C. 1.4.1.3/L), NADH diaphorase (DIA/E.C. 1.6.2.2/K,L), catalase (CE/E.C. 1.11.1.6/L), superoxide dismutase (SOD/E.C. $1.15 .1 .1 / \mathrm{K}$ ), purine nucleoside phosphorylase (NP/E.C. 2.4.2.1/K), glutamate oxaloacetate transaminase (GOT/2.6.1.1/K), hexokinase (HK/E.C. 2.7.1.1/H), creatine kinase (CK/E.C. 2.7.3.2/H), adenylate kinase (AK/E.C. 2.7.4.3/H), phosphoglucomutase (PGM/E.C. 2.7.5.1/K), esterases (ES/E.C. 3.1.1.1/K,M), alkaline phosphatase (ALP/E.C. 3.1.3.1/K), acid phosphatase (ACP/E.C. 3.1.3.2/K), peptidases (PEP/E.C. 3.4.11/K), aminoacylase-1 (ACY-1/E.C. 3.5.1.14/K), adenosine deaminase (ADA/E.C. 3.5.4.4/K), aldolase (ALDO/E.C. 4.1.2.13/B), fumarate hydratase (FH/E.C. 4.2.1.2/L), aconitase (ACO/E.C. 4.2.1.3/L), mannosephosphate isomerase (MPI/E.C. 5.3.1.8/K), glucosephosphate isomerase (GPI/E.C. 5.3.1.9/K).

The genetic interpretation of electrophoretic patterns was based on the principles outlined by Harris (1980) and Harris \& Hopkinson (1976). Furthermore the list of enzyme quaternary structures published by Darnall \& Klotz (1975) was used for the interpretation of heterozygote phenotypes. The most common allele in the bank vole population 1 was designated arbitrarily "100", whereas variant alleles in the same or in other populations were assigned numbers which related their mobility to the mobility of the variant " 100 ".

\section{RESULTS}

\subsection{Electrophoretic Data}

A total of 51 presumptive loci with sufficient resolution for population surveys were identified. Thirty-eight of these were monomorphic in the present material (Gdc, $S d h, L d h-1$ and $-2, M o r-1, I d h-1, G p d, G a p d h$, $\mathrm{Xdh}$, Glud, Dia-1 and $-2, \mathrm{Ce}$, Sod -1 and -2, Got-1 and $-2, H k-1$ and -2 , $C k-1$ and $-2, A k-1$ and $-2, E s-1$ and $-2, A c p-1,-2$ and $-3, P e p-1$ and -2 , Aldo-1 and $-2, F h-1$ and $-2, A c o-1$ and $-2, M p i$, and Gpi). The remaining thirteen loci (Adh, Mor-2, Mod, Idh-2, Pgd, Gdh, Pgm-1, -2 and -3, Es-d, $A l p, A c y-1$, and $A d a$ ) were polymorphic in at least one of the samples. Electrophoretic patterns and results of family studies to prove the genetic basis of enzyme variation in the bank vole will be published 
elsewhere, allelic frequencies are given in Table 1. Genetic variability within populations was quantified by calculating the proportion of polymorphic loci $(\bar{P})$, expected average heterozygosity $(\bar{H})$ and the mean number of alleles per locus $(\bar{A})$ (Table 2$)$. The mean $\bar{P}$-value $(99 \%$ criterion) was found to be 0.158 (range $0.078-0.216$ ). The mean proportion of heterozygosity per individual was 0.057 (range $0.028-0.085$ ). The mean value for $\bar{A}$ observed in our populations was 1.21 (range 1.10 $-1.31)$.

Considering the age of the 13 populations studied, they can be partitioned into two groups. According to previous faunistic investigations (Bauer, 1960 and personal communication) populations 1, 4, 7, 9, 10, 11, and 12 (group I) represent large old stocks whereas populations 2, 3, 5, 6,8 , and 13 (group II) root back to invaders of young zones of reforestation within the last three decades. If we calculate mean $\overline{\mathrm{P}}$ and $\overline{\mathrm{H}}$ separately for each group we obtain $\overline{\mathrm{P}}=0.176 \quad( \pm 0.032)$ and $\overline{\mathrm{H}}=0.068$ $( \pm 0.012)$ for group $I$, and $\bar{P}=0.137( \pm 0.045)$ and $\bar{H}=0.043( \pm 0.010)$ for group II. Mean $\bar{H}$ in group I was significantly higher than in group II (Mann-Whitney U-Test, $p<0.005$ ). Based on allelic frequencies (Table 1) genetic similarity between populations was estimated using Nei's (1978) measures of overall genetic identity $(I)$ and standard genetic distance $(D)$ corrected for small sample sizes. Calculated over all populations mean genetic identity was $0.993( \pm 0.005)$ and mean genetic distance was 0.007 ( \pm 0.005 ), respectively. Mean $I$ among populations of group I was $0.995( \pm 0.004)$, mean $D$ was $0.004( \pm 0.004)$. Mean $I$ among populations of group II was $0.992( \pm 0.005)$ and mean $D$ was $0.008( \pm 0.005)$.

The total amount of genetic variation was further analyzed using Nei's (1975) measures of gene diversity. The average diversity among populations $\left(D_{\mathrm{ST}}\right)$ was 0.009 and accounted for approximately $13.4 \%$ $\left(G_{\mathrm{ST}}=0.134\right)$ of the total gene diversity $\left(H_{\mathrm{T}}=0.066\right)$. If only the populations of group I are considered, merely $8.7 \%$ of the total gene diversity are due to gene differentiation among populations $\left(D_{\mathrm{ST}}=0.007, G_{\mathrm{ST}}=0.087\right.$ $\left.H_{\mathrm{T}}=0.075\right)$.

\subsection{Genetic Variation Among Enzyme Classes}

The mean proportions of $\bar{P}, \bar{H}$ and $\bar{A}$ have been recalculated in three different ways. Following Ward (1977) we partitioned the total set of enzyme systems according to their quaternary structure: group I, monomeric enzymes (14 loci); group II, dimeric enzymes (19 loci); group III, tetrameric enzymes (11 loci). The results for these three groups, respectively, were: $\bar{P}=0.236,0.203,0.077 ; \bar{H}=0.081,0.074,0.032 ; \bar{A}=1.297$, $1.259,1.119$. 


\begin{tabular}{|c|c|c|}
\hline 吾 & ఇक्र & 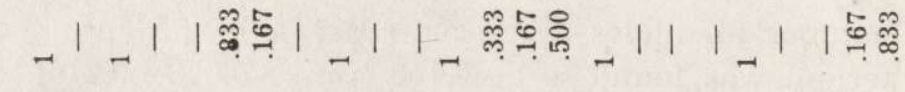 \\
\hline & $\underbrace{*} \circledast$ & 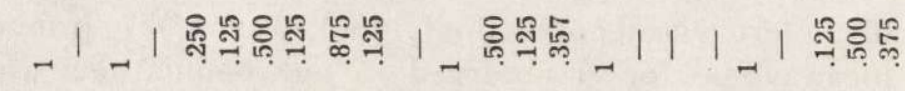 \\
\hline & $\doteqdot E$ & 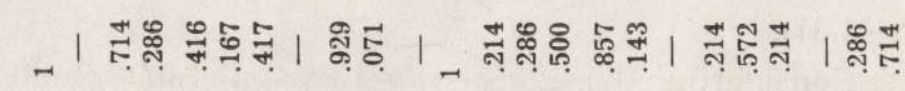 \\
\hline & $\ddot{g} E$ & 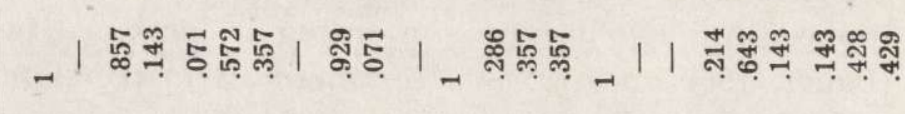 \\
\hline & 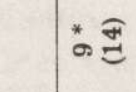 & 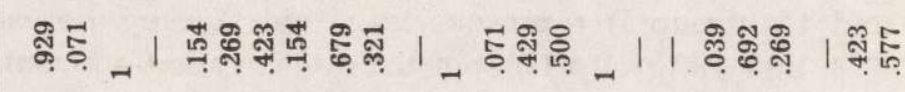 \\
\hline & $\infty \varepsilon$ & 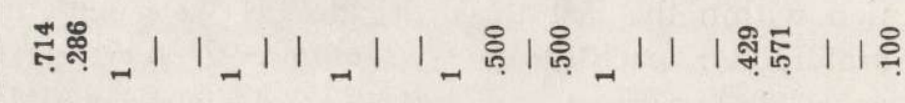 \\
\hline & *6 & 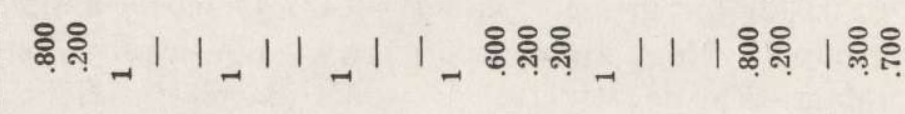 \\
\hline & $\overbrace{}^{\infty E}$ & 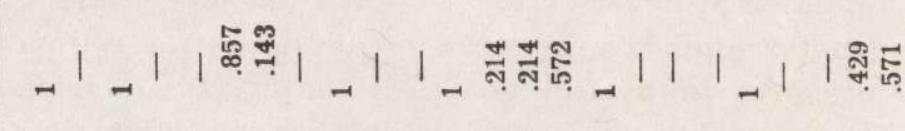 \\
\hline & 这 & 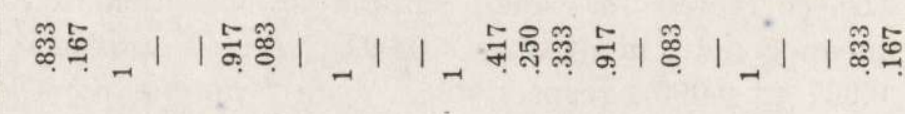 \\
\hline & $\div \bar{\Omega}$ & 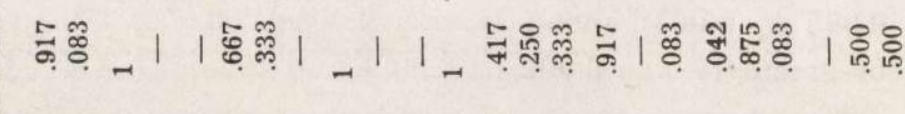 \\
\hline & $\infty \varrho$ & 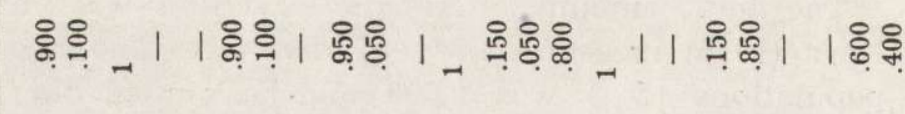 \\
\hline & ब్ & 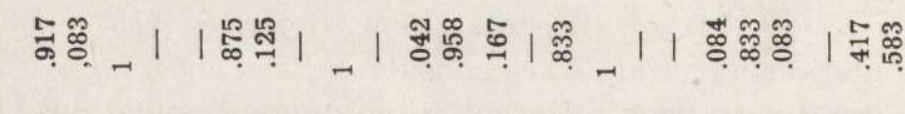 \\
\hline & $\because \varrho$ & కిష్టి _| | | \\
\hline & $\stackrel{\square}{\rightleftarrows}$ & 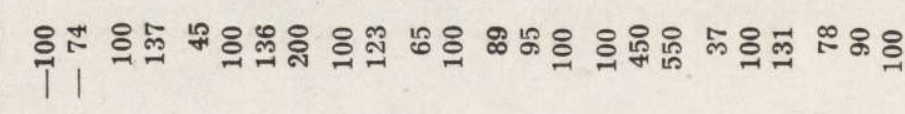 \\
\hline & $\frac{n}{\tilde{z}^{2}}$ & ๘ \\
\hline
\end{tabular}




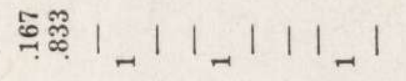

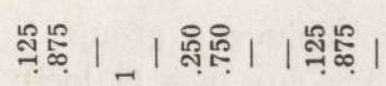

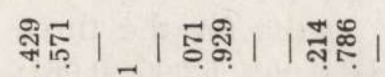

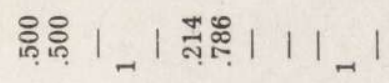

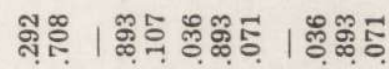
สุ่

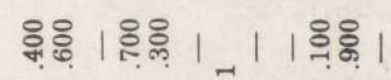

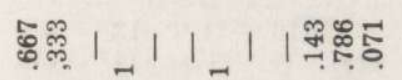

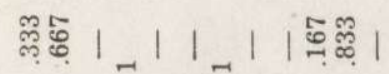

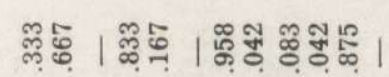

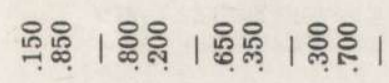

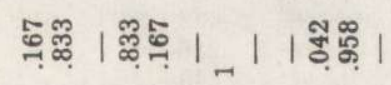

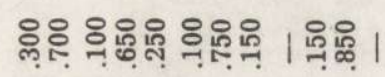

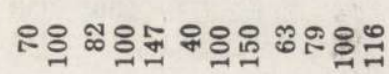

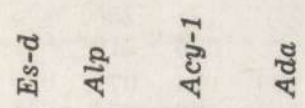


Furthermore, according to Gillespie \& Kojima (1968), the whole set of enzymes was partitioned into: group I, glucose metabolizing enzymes (28 loci); group II, other enzymes (23 loci). The results for the two groups, respectively, were: $\bar{P}=0.159,0.157 ; \bar{H}=0.065,0.047 ; \bar{A}=1.228$, 1.174 .

The third grouping, following Johnson (1974) included: group I, regulatory enzymes (14 loci); group II, nonregulatory enzymes (9 loci); group III, variable substrate enzymes $(9$ loci). The results for the three groups, respectively, were: $\bar{P}=0.258,0.026,0.171 ; \bar{H}=0.095,0.006,0.061$; $\bar{A}=1.352,1.025,1.179$.

Table 2

Observed and expected (below) heterozygosity $(\bar{H})$ at each of the 13 polymorphic loci studied in 13 populations of the bank vole. Observed and expected (below) average heterozygosity $(\bar{H})$ were calculated including 38 monomorphic loci. $\bar{P}-$ proportion of polymorphic loci, $\bar{A}$ - mean number of alleles per locus, sample sizes in brackets, ${ }^{*}$ - populations of group I.

\begin{tabular}{|c|c|c|c|c|c|c|c|c|c|c|c|c|c|}
\hline \multirow[b]{2}{*}{ Locus } & \multicolumn{13}{|c|}{ Populations: } \\
\hline & $\begin{array}{c}1^{*} \\
(10)\end{array}$ & $\begin{array}{c}2 \\
(12)\end{array}$ & $\begin{array}{c}3 \\
(10)\end{array}$ & $\begin{array}{c}4^{*} \\
(12)\end{array}$ & $\begin{array}{c}5 \\
(6)\end{array}$ & $\begin{array}{c}6 \\
(7)\end{array}$ & $\begin{array}{l}7^{*} \\
(5)\end{array}$ & $\begin{array}{c}8 \\
(7)\end{array}$ & $\begin{array}{c}9^{*} \\
(14)\end{array}$ & $\begin{array}{c}10^{*} \\
(7)\end{array}$ & $\begin{array}{r}11^{*} \\
(7)\end{array}$ & $\begin{array}{l}12^{*} \\
(4)\end{array}$ & $\begin{array}{l}13 \\
(3)\end{array}$ \\
\hline Adh & & .167 & .200 & .167 & $\begin{array}{l}.333 \\
278\end{array}$ & - & $\begin{array}{l}.400 \\
320\end{array}$ & $\begin{array}{l}.571 \\
408\end{array}$ & $\begin{array}{l}.143 \\
132\end{array}$ & - & - & - & - \\
\hline Mor-2 & $\frac{.320}{-}$ & $\frac{.152}{-}$ & .180 & 152 & - & 一 & - & - & - & $\begin{array}{l}.286 \\
.245\end{array}$ & $\begin{array}{l}.571 \\
.408\end{array}$ & - & - \\
\hline Mod & $\begin{array}{l}.300 \\
.495\end{array}$ & $\begin{array}{l}.250 \\
.219\end{array}$ & $\begin{array}{l}.200 \\
.180\end{array}$ & $\begin{array}{l}.333 \\
.444\end{array}$ & $\begin{array}{l}.167 \\
.152\end{array}$ & $\begin{array}{l}.286 \\
.245\end{array}$ & - & - & $\begin{array}{l}.692 \\
.701\end{array}$ & $\begin{array}{l}.429 \\
.540\end{array}$ & $\begin{array}{l}.833 \\
.625\end{array}$ & $\begin{array}{l}.750 \\
.656\end{array}$ & $\begin{array}{l}.333 \\
.278\end{array}$ \\
\hline Idh-2 & $\begin{array}{l}.200 \\
.180\end{array}$ & - & $\begin{array}{l}.100 \\
.095\end{array}$ & - & - & - & - & - & $\begin{array}{l}.643 \\
.436\end{array}$ & $\begin{array}{l}.143 \\
.132\end{array}$ & $\begin{array}{l}.143 \\
.132\end{array}$ & $\begin{array}{l}.250 \\
.219\end{array}$ & -218 \\
\hline Pgd & - & $\begin{array}{l}.083 \\
.080\end{array}$ & - & - & - & - & - & - & - & - & - & - & \\
\hline Gdh & $\begin{array}{l}.400 \\
.620\end{array}$ & $\begin{array}{l}.333 \\
.278\end{array}$ & $\begin{array}{l}.200 \\
.335\end{array}$ & $\begin{array}{l}.200 \\
.653\end{array}$ & $\begin{array}{l}.667 \\
.653\end{array}$ & $\begin{array}{l}.286 \\
.583\end{array}$ & $\begin{array}{l}.600 \\
.560\end{array}$ & $\begin{array}{l}.429 \\
.500\end{array}$ & $\begin{array}{l}.643 \\
.561\end{array}$ & $\begin{array}{l}.429 \\
.663\end{array}$ & $\begin{array}{l}.714 \\
.622\end{array}$ & $\begin{array}{l}.750 \\
.594\end{array}$ & $\begin{array}{l}.667 \\
.611\end{array}$ \\
\hline Pgm-1 & $\begin{array}{l}.100 \\
.095\end{array}$ & - & - & $\begin{array}{l}.167 \\
.152\end{array}$ & $\begin{array}{l}.167 \\
.152\end{array}$ & - & - & - & - & - & $\begin{array}{l}.286 \\
.245\end{array}$ & - & - \\
\hline Pgm-2 & $\begin{array}{l}.400 \\
.595\end{array}$ & $\begin{array}{l}.167 \\
.292\end{array}$ & $\begin{array}{l}.300 \\
.255\end{array}$ & $\begin{array}{l}.250 \\
.226\end{array}$ & - & - & $\begin{array}{l}.000 \\
.320\end{array}$ & $\begin{array}{l}.286 \\
.490\end{array}$ & $\begin{array}{l}.462 \\
.447\end{array}$ & $\begin{array}{l}.571 \\
.520\end{array}$ & $\begin{array}{l}.286 \\
.581\end{array}$ & - & - \\
\hline Pgm-3 & $\begin{array}{l}.300 \\
.455\end{array}$ & $\begin{array}{l}.667 \\
.486\end{array}$ & $\begin{array}{l}.200 \\
.480\end{array}$ & $\begin{array}{l}.833 \\
.500\end{array}$ & $\begin{array}{l}.000 \\
.278\end{array}$ & $\begin{array}{l}.571 \\
.490\end{array}$ & $\begin{array}{l}.200 \\
.420\end{array}$ & - & $\begin{array}{l}.385 \\
.488\end{array}$ & $\begin{array}{l}.429 \\
.612\end{array}$ & $\begin{array}{l}.286 \\
.408\end{array}$ & $\begin{array}{l}.750 \\
.594\end{array}$ & $\begin{array}{l}.333 \\
.278\end{array}$ \\
\hline$E s-d$ & $\begin{array}{l}.400 \\
.420\end{array}$ & $\begin{array}{l}.333 \\
.278\end{array}$ & $\begin{array}{l}.100 \\
.255\end{array}$ & $\begin{array}{l}.500 \\
.444\end{array}$ & $\begin{array}{l}.666 \\
.444\end{array}$ & $\begin{array}{l}.333 \\
.444\end{array}$ & $\begin{array}{l}.800 \\
.480\end{array}$ & $\begin{array}{l}.142 \\
.336\end{array}$ & $\begin{array}{l}.583 \\
.413\end{array}$ & $\begin{array}{l}.714 \\
.500\end{array}$ & $\begin{array}{l}.571 \\
.489\end{array}$ & $\begin{array}{l}.250 \\
.218\end{array}$ & $\begin{array}{l}.333 \\
.278\end{array}$ \\
\hline Alp & $\begin{array}{l}.700 \\
.505\end{array}$ & $\begin{array}{l}.333 \\
.278\end{array}$ & $\begin{array}{l}.400 \\
.320\end{array}$ & $\begin{array}{l}.333 \\
.278\end{array}$ & I & $\overline{-}$ & $\begin{array}{l}.600 \\
.420\end{array}$ & $\begin{array}{l}.143 \\
.132\end{array}$ & $\begin{array}{l}.071 \\
.191\end{array}$ & $\overline{-}$ & E & = & $=$ \\
\hline Acy-1 & $\begin{array}{l}.500 \\
.405\end{array}$ & - & $\begin{array}{l}.500 \\
.455\end{array}$ & $\begin{array}{l}.083 \\
.081\end{array}$ & - & - & - & $\begin{array}{l}.286 \\
.245\end{array}$ & $\begin{array}{l}.214 \\
.196\end{array}$ & $\begin{array}{l}.429 \\
.336\end{array}$ & $\begin{array}{l}.143 \\
.132\end{array}$ & $\begin{array}{l}.500 \\
.375\end{array}$ & - \\
\hline Ada & $\begin{array}{l}.300 \\
.255\end{array}$ & $\begin{array}{l}.083 \\
.080\end{array}$ & $\begin{array}{l}.600 \\
.420\end{array}$ & $\begin{array}{l}.083 \\
.226\end{array}$ & $\begin{array}{l}.333 \\
.278\end{array}$ & $\begin{array}{l}.429 \\
.357\end{array}$ & $\begin{array}{l}.200 \\
.180\end{array}$ & $\begin{array}{l}.000 \\
.245\end{array}$ & $\begin{array}{l}.214 \\
.196\end{array}$ & - & $\begin{array}{l}.143 \\
.336\end{array}$ & $\begin{array}{l}.250 \\
.219\end{array}$ & - \\
\hline H & $\begin{array}{l}.074 \\
.085\end{array}$ & $\begin{array}{l}.045 \\
.042\end{array}$ & $\begin{array}{l}.059 \\
.058\end{array}$ & $\begin{array}{l}.053 \\
.062\end{array}$ & $\begin{array}{l}.036 \\
.044\end{array}$ & $\begin{array}{l}.034 \\
.042\end{array}$ & $\begin{array}{l}.044 \\
.053\end{array}$ & $\begin{array}{l}.037 \\
.046\end{array}$ & $\begin{array}{l}.075 \\
.074\end{array}$ & $\begin{array}{l}.059 \\
.070\end{array}$ & $\begin{array}{l}.074 \\
.078\end{array}$ & $\begin{array}{l}.071 \\
.056\end{array}$ & $\begin{array}{l}.029 \\
.028\end{array}$ \\
\hline $\bar{P}$ & .216 & .177 & .196 & .196 & .137 & .098 & .137 & .137 & .196 & .160 & .196 & .137 & .078 \\
\hline $\bar{A}$ & 1.29 & 1.20 & 1.22 & 1.25 & 1.16 & 1.14 & 1.16 & 1.13 & 1.31 & 1.24 & 1.25 & 1.22 & 1.10 \\
\hline
\end{tabular}




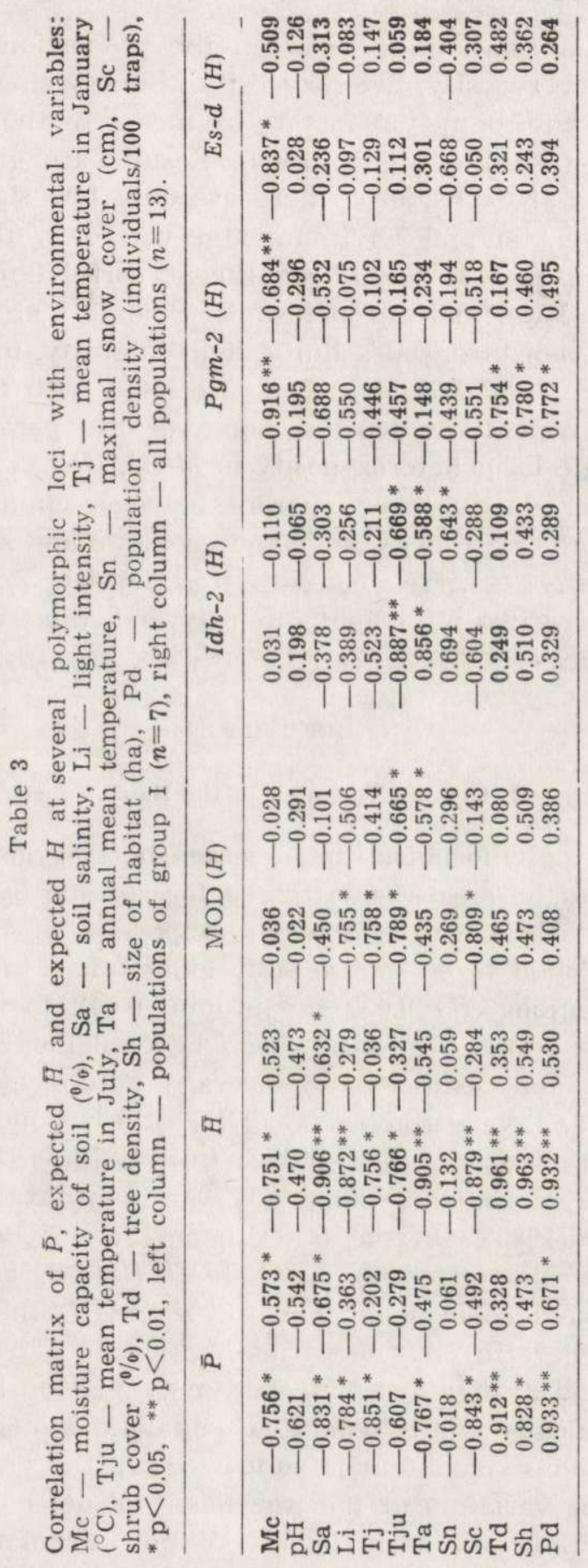




\subsection{Environmental Correlates of Genetic Variation}

We investigated relationship between the proportion of polymorphic loci, average heterozygosity, heterozygosity at every single variable locus and each of the environmental factors by means of the Pearsonian correlation method (Sokal \& Rohlf, 1969). Results are given in Table 3. If all populations are considered there are only few significant correlations between genetic and environmental variables. However, if only group I is taken several highly significant correlations are apparent. The following are the main conclusions: $\bar{P}$ and $\bar{H}$ are negatively correlated with soil moisture, soil salinity, light intensity, mean temperature and shrub cover. They are positively correlated with tree density, size of habitat and population density. Some of the parameters are correlated with single locus heterozygosity in $M O D, I D H-2, P G M-2$ and $E S-D$ (Table 3). No correlations are apparent between climatological factors and any of the other variables and between biotic and soil factors. Light intensity is negatively correlated with tree density. Population density is highly intercorrelated with light intensity and, thus, with tree density and size of habitat.

\section{DISCUSSION}

\subsection{Genetic Variation in the Bank Vole}

The extent of polymorphism and average heterozygosity in the bank vole is similar to the mean values given for rodents by Selander (1976) and Nevo (1978). However, the mean proportion of heterozygous loci $(\bar{H}=0.068)$ was found to be considerably higher than in previous studies on Polish populations $(\bar{H}=0.032$ in autumn, 0.042 in spring; Fedyk \& Gębczyński, 1980). This discrepancy can be explained in two different ways. On one hand, estimates of average heterozygosity depend on number of loci and their composition (Nei \& Roychoudhury, 1974; Nei, 1978; Gorman \& Renzi, 1979; Hartl \& Csaikl, 1987). Several isozymes found to be polymorphic in our study were not examined by Fedyk and Gębczyński (1980). On the other hand, among Polish populations polymorphism was detected in $G D C, L D H(L d h-1$, and -2$)$ and $A K$, which were monomorphic in all Austrian samples. Since there are considerable differences in enzyme variability within a narrow geographic area (Tables 1 and 2; Figs 1 and 2), there may be even larger differences among geographically more separated populations of this widespread species. The latter explanation is supported by the environmental correlates of genetic variation at the isozyme level detected in the present study, which will be discussed below. Within our material an obvious difference in $\bar{P}$ and $\bar{H}$ was detected between old (group I) and newly 
established (group II) populations, the latter exhibiting lower levels of genetic variation. Allelic frequencies at some enzyme loci in one or the other population of group II are very different from all other populations studied (Table 1) which, for instance, can also be seen in the unexpected position of population 8 in the dendrogram (Fig. 2), fitting very well to geographic distribution in the old populations. Accordingly, if all populations are considered, a higher amount of the total gene diversity was due to interpopulational gene diversity (13.4\%), than anly among the old populations (8.7\%). These differences in allelic frequencies and gene diversity may be the result of founder effects and genetic drift due to initially small individual numbers of the newly established populations.

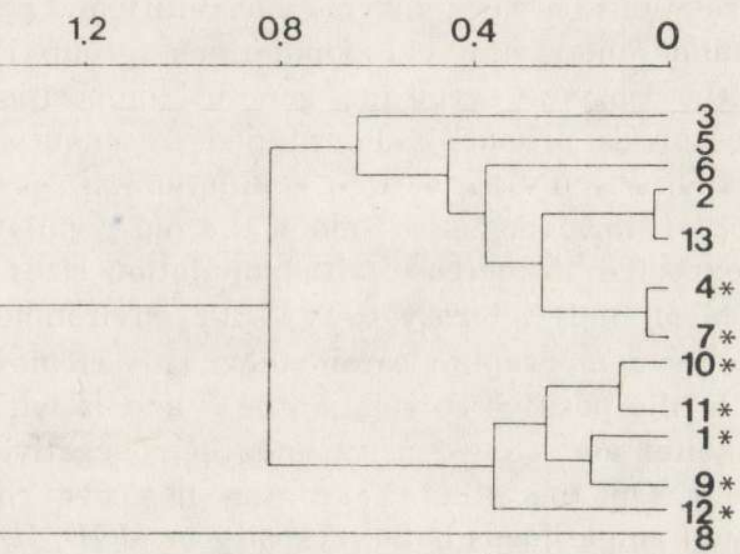

Fig. 2. Dendrogram constructed using the UPGMA based on pairwise genetic distances (D, Nei 1978) $\times 100,{ }^{*}-$ populations of group I.

\subsection{Enzyme Variability and Selection}

From the viewpoint of the neutral theory of molecular evolution (see Nei, 1975 for review) random events are the main determinants for differences in enzyme variation among populations or species. However, an increasing body of data becomes available, suggesting that at least part of enzyme variation is associated with environmental variables (e.g. Mitton \& Koehn, 1975; Nevo \&Yang, 1982; Nevo, 1983a, b) and that different phenotypes in several isozymes exhibit different kinetic properties (Watt, 1985; Watt et al., 1983; Clarke, 1975). Differences in the extent of polymorphism among various enzyme classes were found and explained as the result of Darwinian selection. Enzymes which utilize variable substrates or regulate the flow of metabolites are more variable due to a greater adaptive potential than enzymes, which have single suostrates in relatively constant concentrations (e.g. Powell, 1975; John- 
son, 1974; Gillespie \& Langley, 1974). This hypothesis is supported by our data, but only as far as the grouping of Johnson (1974) is concerned. On the other hand, our data are also consistent with the explanation of Ward (1977), suggesting that monomeric or dimeric enzymes are more polymorphic than tetramers, the latter being more exposed to purifying selection (which is accepted also by neutralists) due to their complex spatial structure. In conclusion we think, that differences in genetic variation between enzyme systems are created by a complex pattern of positive and purifying selective forces, overlapping at least in several enzymes such as phosphoglucomutase or esterases (enhanced positive and less purifying selection).

Concerning the environmental correlates of genetic variation most of the significant correlations between enzyme variability and environmental variables were found among the old populations (group I). This may indicate, that at the isozyme level the genetic composition of newly established populations is primarily determined by chance effects and selection becomes invisible until a certain population size is reached and remains rather stable. However, since among the old populations genetic variation can be expected to increase with population sizes the correlation of polymorphism and heterozygosity with environmental factors may also reflect only demographic parameters. This is most likely the case with respect to the positive correlation of $\bar{P}$ and $\bar{H}$ with population density, size of habitat and tree density and their negative correlation with light intensity. On the other hand, the negative correlation of $\overline{\mathrm{P}}, \overline{\mathrm{H}}$ and especially of single locus heterozygosity in $M O D, I D H-2, P G M-2$ and $E S-D$ with climatic and soil factors cannot be explained by different population densities. All these isozymes are regulatory (MOD, IDH-2, $P G M-2)$ and variable substrate $(E S-D)$ enzymes, respectively, which are expected to be more susceptible to Darwinian selection (Johnson, 1974; Hochanchka \& Somero, 1980). Furthermore different contributions of allozyme phenotypes to fitness were described e.g. in PGM-2 in the wood mouse (see Berry, 1985) and in esterases in the bank vole (Wójcik \& Fedyk, 1984; Hall \& Semeonoff, 1985). Therefore ecophysiological adaptation may be in part responsible for differences in genetic variation,, especially for phenotype distribution in the isozymes mentioned above. More detailed field studies and breeding experiments are at work to investigate the relationship between enzyme phenotypes and various fitness components with respect to metabolism and environmental variation.

Acknowledgements. The authors are indebted to Dr. Hans Winkler, who performed part of statistical analyses, to Mag. Inge Lieskounig, who prepared the figures, to $\mathrm{Mr}$. Herbert Hoi for dynamical help in sampling and to Dipl. Ing. Dr. Kurt Bauer for stimulating discussions. The study was supported by a grant of the Austrian Research Foundation. 


\section{REFERENCES}

1. Ayala F. J. \& Powell J. R., 1972: Enzyme variability in the Drosophila willistoni group VI. Levels of polymorphism and the physiological function of enzymes. Biochemical Genetics, $7: 331-345$.

2. Bauer K., 1960: Die Säugetiere des Neusiedlersee-Gebietes. Bonn. zool. Beitr., 11: $141-344$.

3. Berry R. J., 1985: Evolutionary and ecological genetics of the bank vole and wood mouse. [In.: J. R. Flowerdew, J. Gurnell and J. H. Gipps (eds.), "The ecology of woodland rodents, bank voles and wood mice"] Clarendon Press, Oxford: $1-31$.

4. Clarke B., 1975: The contribution of ecological genetics to evolutionary theory. detecting the direct effects of natural selection on particular polymorphic loci. Genetics, 79: 101-113.

5. Darnall D. S. \& Klotz I. M., 1975: Subunit constitution of proteins: a table. Arch. Biochem. Biophys., 166: 651-681.

6. Fedyk A. \& Gębczyński M., 1980: Genetic changes in seasonal generations of the bank vole. Acta theriol., 25: 475-485.

7. Frasl G., 1961: Zur Petrographie der Böden des Seewinkels. Mitt. österr. Bodenkundl. Ges., 6: 62-67.

8. Gillespie J. H. \& Kojima K., 1968: The degree of polymorphism in enzymes involved in energy production compared to that in non-specific enzymes in two Drosophila ananassae populations. Proc. Nat. Acad. Sci. U.S.A., 61: 582-585.

9. Gillespie J. H. \& Langley C. H., 1974: A general model to account for enzyme variation in natural populations. Genetics, 76: 837-884.

10. Gorman G. C. \& Renzi J. Jr., 1979: Genetic distance and heterozygosity estimates in electrophoretic studies: effects of sample size. Copeia, 2: 242-249.

11. Greig-Smith P., 1964: Quantitative plant ecology, 2nd ed., Butterworth Washington, D.C.

12. Hall S. J. G. \& Semeonoff R., 1985: Plasma esterase polymorphism in the bank vole, Clethrionomys glareolus, in Britain. J. Zool., Lond., 207: 213-222.

13. Harris H., 1980: The principles of human biochemical genetics. North Holland, Amsterdam, 1-554.

14. Harris H. \& Hopkinson D. A., 1976: Handobook of enzyme electrophoresis in human genetics. North Holland, Amsterdam.

15. Hartl G. B. \& Höger H., 1986: Biochemical variation in purebred and crossbred strains of domestic rabbits. Genetical Research, Cambridge, 48: 27-34.

16. Hartl G. B. \& Csaikl F., 1987: Genetic variability and differentiation in wild boars (Sus scrofa ferus L.): comparison of isolated populations. J. Mamm, 68: $119-125$.

17. Hochachka P. W. \& Somero G. N., 1980: Strategien biochemischer Anpassung. Thieme, Stuttgart.

18. Hübl E., 1959: Die Wälder des Leithagebirges. Verh. Zool. Bot. Ges. Wien, 98/99: 96-167.

19. Husz G., 1962: Zur Bodenkartierung im Salzbodenbereich des Seewinkels. Wiss. Arb. Bgld. (Eisenstadt), 29: 172-179.

20. Johnson G. B., 1974: Enzyme polymorphism and metabolism. Science, 184: 28-37.

21. Johnson G. B., 1976: Genetic polymorphism and enzyme function. [In: F. J. Ayala (ed.), "Molecular evolution"] Sinauer Associates, Sunderland: 47-59.

22. Köllner J. E., 1983: Vegetationsstudien im westlichen Seewinkel (Burgenland) 
- Zitzmannsdorfer Wiesen und Salzlackenränder. Unpublished $\mathrm{PhD}$-Thesis, Univ. Salzburg, Austria.

23. Leitner M., 1987: Zur Veränderung der Kleinsäugerfauna des Neusiedlerseegebietes im Verlauf der letzten drei Jahrzehnte. Unpublished PhD-Thesis, Univ. Wien, Austria.

24. Lewontin R. C., 1985: Population genetics. Ann. Rev. Gent., 19: 81-102.

25. Mitton J. B. \& Koehn R. K., 1975: Genetic organization and adaptive response of allozymes to ecological variables in Fundulus heteroclitus. Genetics, 79: 97-111.

26. Mühlenberg M., 1976: Freilandökologie. Quelle \& Meyer, Heidelberg.

27. Nei M., 1975: Molecular population genetics and evolution. North Holland, Amsterdam. 1-288.

28. Nei M., 1978: Estimation of average heterozygosity and genetic distance from a small number of individuals. Genetics, 89: 583-590.

29. Nei M. \& Roychoudhury A. K., 1974: Sampling variances of heterozygosity and genetic distance. Genetics, 76: 379-390.

30. Nevo E., 1978: Genetic variation in natural populations: patterns and theory. Theor. Pop. Biol., 13: 121-177.

31. Nevo E., 1983a: Population genetics and ecology: the interface. [In: D. S. Bendall (ed.) "Evolution from molecules to men"] University Press, Cambridge: $287-321$.

32. Nevo E., 1983b: Adaptive significance of protein variation. [In: G. S. Oxford and D. Rollinson (eds.). "Protein polymorphism, adaptive and taxonomic significance"] Academic Press, London: 239-282.

33. Nevo E. \& Yang S. Y., 1982: Genetic diversity and ecological relationships of marsh frog populations in Israel. Theor. Appl. Genet., 63: 317-330.

34. Powell J. R., 1975: Protein variation in natural populations of animals. [In: T. Dobzhansky, M. K. Hecht, \& W. C. Steere (eds.) "Evolutionary biology"] 8: 79-119, Plenum, New York.

35. Pucek IM., 1983: Habitat of the population. [In: K. Petrusewicz (ed.) "Ecology of the bank vole"] Acta theriol., 28, Suppl. 1: 31-49.

36. Raczyński J., 1983: Taxonomic position of the bank vole. [In: K. Petrusewicz (ed.) "Ecology of the bank vole"] Acta theriol., 28, Suppl. 1: 3-10.

37. Sarich V. M., 1977: Rates, sample sizes and the neutrality hypothesis in evolutionary studies. Nature, 265: $24,28$.

38. Schuster B., 1977: Trockenrasen im Burgenland. Ber. biol. Forschungsinst. Bgld. (Illmitz), 19.

39. Selander R. K., 1976: Genetic variation in natural populations. [In: F. J. Ayala (ed.) "Molecular Evolution"] Sinauer Associates, Sunderland: 21-45.

40. Shaw C. R. \& Prasad R., 1970: Starch gel electrophoresis of enzymes - a compilation of recipes. Biochemical Genetics, 4: 297-320.

41. Siciliano M. J. \& Shaw C. R., 1976: Separation and visualization of enzymes on gels. [In: I. Smith (ed.) "Chromatographic and electrophoretic techniques"] William Heinemann, London: 185-209.

42. Smith R. L., 1980: Ecology and field biology. Harper \& Row, New York.

43. Sokal R. R. \& Rohlf F. J., 1969: Biometry. W. H. Freeman and Co., San Francisco.

44. Ward R. D., 1977: Relationship between enzyme heterozygosity and quaternary structure. Biochemical Genetics, 15: 123-135.

45. Watt W. B., 1985: Bioenergetics and evolutionary genetics: opportunities for new synthesis. Am. Nat., 125: 118-143. 
46. Watt W. B. et al., 1983: Adaptation at specific loci III. Field behavior and survivorship differences among Colias PGI genotypes are predictable from in vitro biochemistry. Genetics, 10: 725-739.

47. Weiser P., 1970: Die Vegetationsverhältnisse des Neusiedlersees, pflanzensoziologische und ökologische Studien. Wiss. Arb. Bgld., 45: 1-83.

48. Wendelberger G., 1954: Steppen, Trockenrasen und Wälder des pannonischen Raumes (Zugleich Versuch einer Neufassung der Osmatra-Theorie als Waldsteppentheorie). Angewandte Pflanzensoziologie, Festschrift f. E. Aichinger. p. $573-634$.

49. Wójcik A. M. \& Fedyk S., 1984: Breeding parameters in the bank vole of different esterase phenotypes. Acta theriol., 29: 305-316.

Received 1 September 1987, Accepted 6 January 1988.

Maria LEITNER i Günther B. HARTL

GENETYCZNA ZMIENNOSC NORNICY RUDEJ CLETHRIONOMYS GLAREOLUS: BIOCHEMICZNE ZROŻNICOWANIE BLISKICH GEOGRAFICZNIE POPULACJI

\section{Streszczenie}

Zmienność elektroforetyczna enzymów kodowanych przez 51 przypuszczalnych strukturalnych loci badana była w 13 populacjach nornicy rudej (Clethrionomys glareolus we wschodniej Austrii (Ryc. 1). Sredni udzial loci polimorficznych $(\bar{P})$ wynosił 0.158 (zasięg $0.078-0.216$ ) a średnia heterozygotyczność $(\bar{H})$ na osobnika 0.057 (zasięg 0.028-0.085). Dane te są zbliżone do średnich wartości dla gryzoni.

$\mathrm{Na}$ terenie badań wyróżniono 7 populacji endemicznych (grupa I) i 6 populacji utworzonych niedawno na skutek imigracji nornic na tereny zalesiane w ciągu ostatnich 30 lat (grupa II). Wewnątrz tych drugich zmienność genetyczna byla mniejsza, niż wewnątrz populacji z grupy I, ale zróżnicowanie między populacjami było istotnie wyższe (Tabela 1 i 2 ). Wskaźniki $\overline{\mathrm{P}}, \overline{\mathrm{H}}$ oraz heterozygotyczność MOD, $I D H-2, P G M-2$ i ES-D były skorelowane z różnymi cechami środowiska (Tabela 3). Zależności korelacyjne były szczególnie wyraźne w grupie I. Autorzy sugerują, że stopień i rozkład zmienności enzymów w grupie II jest zależny głównie od czynników losowych, natomiast w grupie I znaczna część polimorfizmu może być wynikiem procesów adaptacyjnych. 